\title{
YOUNGEST PRECAMBRIAN DYKE ROCKS IN NORTH KARELIA, EAST FINLAND
}

\author{
AARTO HUHMA
}

\begin{abstract}
HUHMA, Aarto 1981: Youngest Precambrian dyke rocks in North Karelia, East Finland. Bull. Geol. Soc. Finland 53-2, 67-82.

The dykes which are the subject of the present paper are the youngest rocks in the area. These include microtonalite dykes about 1850 Ma old and lamprophyre dykes about $1830 \mathrm{Ma}$ old.

A total of 18 modal and chemical analyses (mainly by XRF) were made on the microtonalite dykes, showing that they vary largely in composition.

Only a few lamprophyre dykes are encountered and one of them was analysed chemically. The dykes are mesocratic biotite-lamprophyres.
\end{abstract}

Aarto Huhma, Laajalahdentie 9 A, SF-00330 Helsinki 33, Finland.

\section{Introduction}

Age determinations from North Karelia show that the oldest Prekarelian rocks, gneisses, are about 2600-2800 Ma old (Simonen 1980). Distinctly younger are the Karelian intrusive rocks (»the Maarianvaara granite»), which date at about $1860 \mathrm{Ma}$ (Huhma 1976). These rocks are cut by distinctly younger dyke rocks, the microtonalite and lamprophyre dykes to be dealt with in this paper (Fig. 1). The lamprophyre dykes have earlier been described by Hackman (1914).

The first lamprophyre dyke was discovered by J. N. Soikero in the summer of 1912 on the western shore of a small lake, Niinilampi, about $1 \mathrm{~km}$ SE of a farm called Hovi. A second dyke was encountered some $1.5 \mathrm{~km}$ farther west. The distance between the dykes is about $2 \mathrm{~km}$.

In the summer of $1913 \mathrm{~V}$. Hackman dis- covered a third dyke only a few metres from the first one. None of the three dykes is thicker than 20 to $30 \mathrm{~cm}$.

Hackman gave a comprehensive description of the mineral composition of the dykes and presented a modal composition and the chemical data on the basis of which he classified the rock as camptonite (ouachitite). As we shall see later, however, the nomenclature is not quite appropriate.

Exploration activity by Outokumpu Oy revealed more dykes in the same area; currently six dykes or parallel dyke swarms are known. Some supplementary studies on the mineral and chemical composition of the dykes were undertaken for this paper.

The microtonalite dykes were first discovered in the course of geological studies at Kaavi in 1954 in the area of map sheet 4311 (Fig. 1). They have been reported previously by Huhma (1970, 1971, 1975, 1976). 


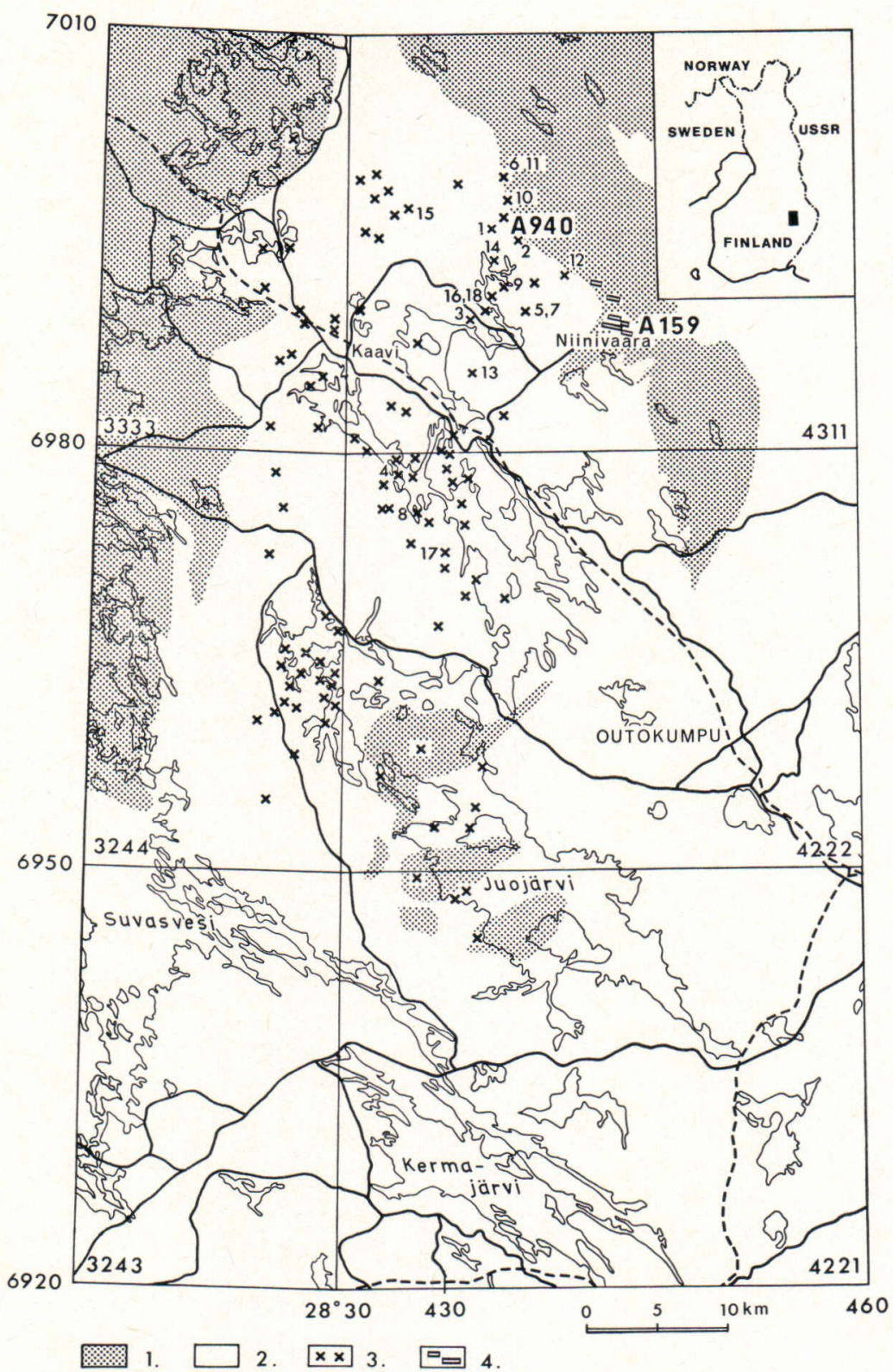

Fig. 1. Simplified geological map of the western part of North Karelia. 1. Prekarelian rocks, 2. Karelian rocks, 3. Microtonalite dykes, 4. Lamprophyre dykes. A940 = Dated microtonalite, A159= Dated lamprophyre, $1-18=$ Analysed microtonalites Tables 1 and 2).

\section{Microtonalite dykes}

\section{Mode of occurence}

Microtonalite dykes (the prefix according to Streckeisen, 1967) abound in a N-S trending zone in the western margins of map sheets
4311 (Sivakkavaara), 4222 (Outokumpu) and 4221 (Heinävesi) and in the eastern parts of map sheets 3333 (Juankoski) and 3244 (Vehmersalmi) (Fig. 1). They have not been discovered outside that area. The dykes are wholly unconnected with any larger plutonic bodies. 


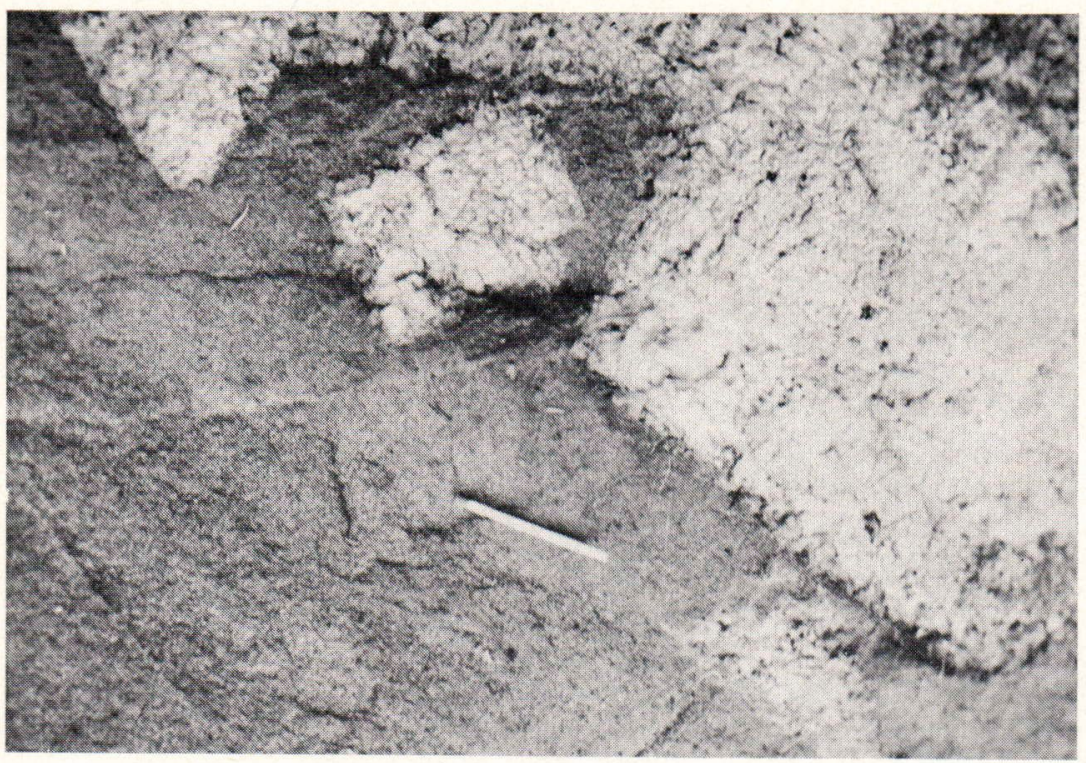

Fig. 2. The contact of a microtonalite dyke with pegmatite granite. A fragment of pegmatite granite is visible in the dyke.
The dykes are from a few centimetres to several metres wide. It has, however, not always been possible to determine their true width because they often occur in the margins of outcrops and thus only one of the contacts is exposed. If both contacts are visible, widths such as $15 \mathrm{~cm}, 50 \mathrm{~cm}, 2 \mathrm{~m}$ and slightly over $10 \mathrm{~m}$ have been measured. The dykes are not very long and can seldom be traced from one outcrop to the next. The longest distance a dyke has been traced is about $50 \mathrm{~m}$; it has been estimated that one other cannot be longer than 15 to $20 \mathrm{~m}$.

Compared with their length, the dykes are often fairly wide and sometimes almost isometric in shape.

The narrow dykes, which are only a few tens of centimetres wide, are generally rectilinear and of constant width and cut the country rock with sharp contacts. In contrast, the wide dykes are of variable width and display contacts that are often zig-zag.

In places the dykes contain country rock fragments, e.g. pegmatite granite in one exposure (Fig. 2). Some of the fragments are rounded, some angular, varying in size from single crystals and quartz feldspar mottles to fragments larger than the palm of a hand.

In another outcrop, dyke rock penetrates mica gneiss, Maarianvaara granite and pegmatite crosscutting and brecciating them so that the dyke rock exhibits mica gneiss (Fig. 3) and granite (Fig. 4) xenoliths with sharp contacts. The latter may be several metres in diameter.

At Mäntyjärvi, Kaavi, there is an outcrop of quartzite with horizontal bedding. The quartzite is crosscut by a subvertical microtonalite dyke that exhibits foliation parallel to the dyke (Figs $5 \mathrm{a}$ and b). This dyke (A 940) has been dated. Another parallel dyke occurs a few metres away.

During mapping undertaken in 1954 a study was made of the joints in a restricted area. This study demonstrated that the joints exhibit four maxima, two of which are associated with the occurrence of microtonalite dykes. The dykes prefer the joint maximum N35W, 75E. Another joint maximum, less often favoured by the dykes, is that of N25W, 


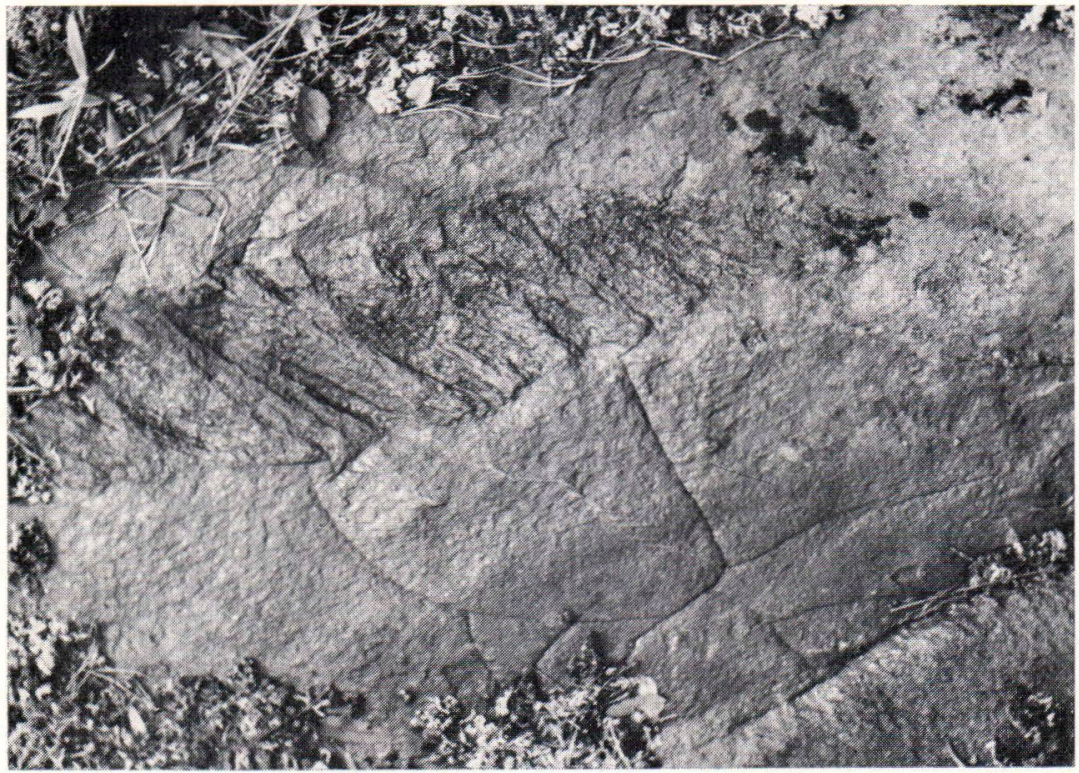

Fig. 3. A fragment of mica gneiss in a microtonalite dyke. The scale as in Fig. 4.
25W. The former represents jointing, whose strike parallels the strike of schistosity but which dips perpendicular to the dip of schistosity. The latter coincides with the jointing parallel to the schistosity.

\section{Petrography}

The microtonalite dykes are fine-grained plagioclase-biotite-quartz rocks and plagioclase-biotite-hornblende-quartz rocks. Potas-
Fig. 4. Fragments of Maarianvaara granite in a microtonalite dyke.

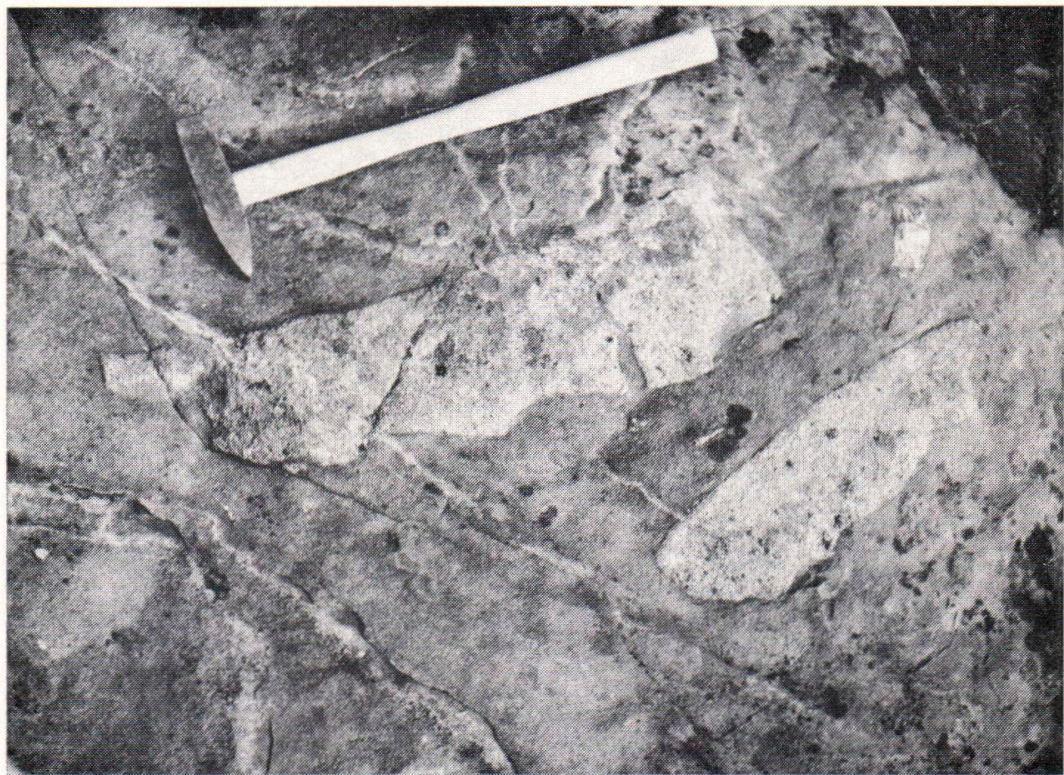




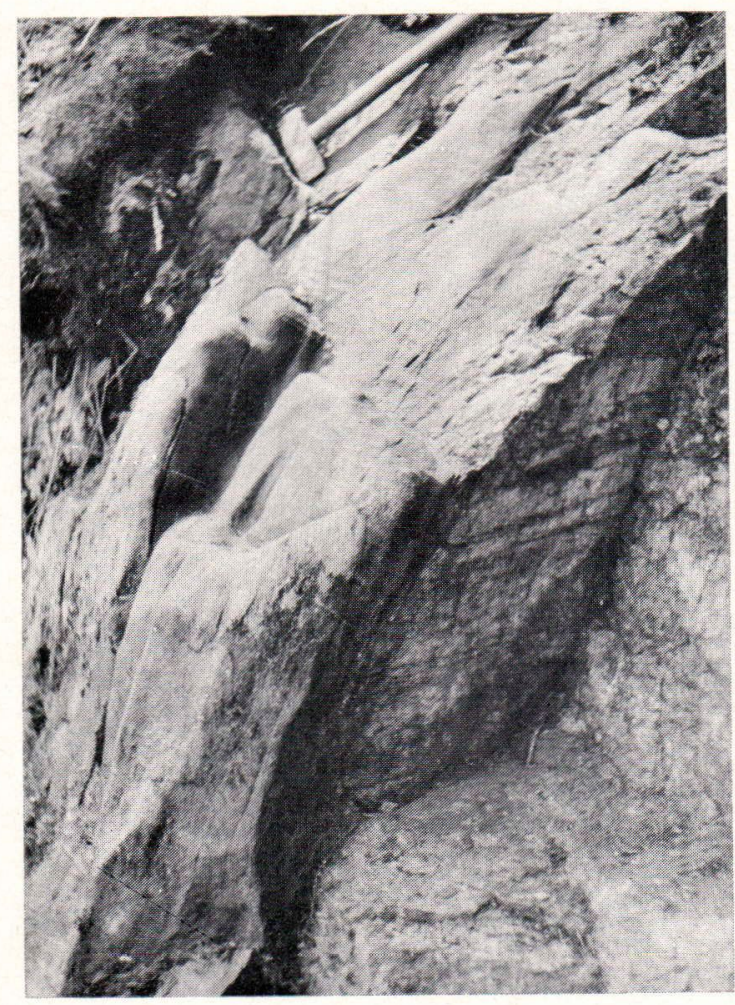

sium feldspar occurs only accessorily, even in the variants richest in quartz. At its most abundant, potassium feldspar is encountered as a secondary fracture filling.

The abundance of quartz varies from a few per cent to almost 30. Biotite tends to be rather common, and plagioclase, whose abundance frequently exeeds $50 \%$, is the predominant mineral. Hornblende may be lacking but it may reach abundances as high as $15.8 \%$ (Table 1 ).

The dykes free from or poor in hornblende resemble fine-grained mica schist (e.g. Fig. 5 a), so much so that, in hand specimens, it is often impossible to distinguish them from mica schist. The dykes are foliated and without layering. To complicate the picture, the mica schist contains non-layered portions.

The grain size of the dykes is fairly small, varying between 0.05 and $0.5 \mathrm{~mm}$. In addition

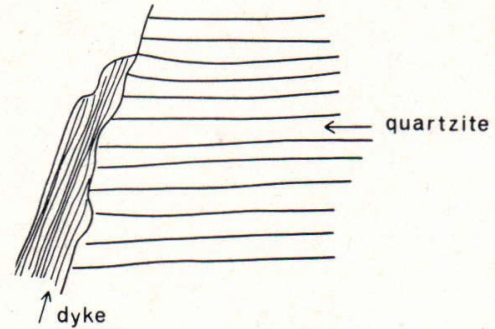

Figs $5 \mathrm{a}$ and $\mathrm{b}$. The contact of quartzite and a microtonalite dyke.

to this rather equigranular rock, some larger euhedral plagioclase phenocrysts ranging up to $1 \times 3.5 \mathrm{~mm}$ in size occur locally (Fig. 6). The more mafic the dyke rock, the more abundant are these phenocrysts. The larger plagioclase phenocrysts in the more acidic dykes are so indistinct that they can seldom be seen macroscopically.

The hornblende-bearing dykes also contain hornblende as larger phenocrysts up to 3 $5 \mathrm{~mm}$ in length. In rocks poor in hornblende this mineral cannot be discerned by the naked eye. Hence, ophitic or porphyritic textures are absent from the dykes.

The equigranular portions exhibit distinct orientation owing to the presence of biotite (and hornblende). Otherwise the rocks are completely homogeneous without any zoning or layering.

The orientation of the larger plagioclase and hornblende phenocrysts often differs from the orientation of the more fine-grained portions.

Plagioclase varies between $\mathrm{An}_{25}$ and $\mathrm{An}_{45}$ in composition and shows only slight sericitization.

The largest plagioclase phenocrysts are characterized by twinning (albite, pericline, Karlsbad). The biotite is reddish brown and intensely pleochroic. The hornblende is bluish green, strongly pleochroic and occurs as blunt prisms. The larger hornblende crystals often 
Table 1. Mineral composition of microtonalite dyke rocks.

\begin{tabular}{|c|c|c|c|c|c|c|c|c|c|c|}
\hline & 1 & 2 & 3 & 4 & 5 & 6 & 7 & 8 & 9 & 10 \\
\hline Quartz & 13.4 & 12.1 & 21.1 & 8.1 & 4.3 & 14.8 & 12.5 & 11.2 & 14.5 & 20.9 \\
\hline Plagioclase & 42.0 & 54.5 & 37.3 & 51.1 & 68.3 & 58.7 & 59.9 & 52.9 & 53.2 & 51.0 \\
\hline (An) & $(40)$ & $(30)$ & $(50-45)$ & $(35-30)$ & $(45-30)$ & $(40)$ & $(45-25)$ & $(30)$ & (40) & $(45-40)$ \\
\hline Biotite & 25.7 & 20.8 & 30.5 & 38.6 & 16.8 & 11.8 & 18.0 & 23.3 & 24.8 & 26.0 \\
\hline Hornblende & 15.8 & 9.2 & 7.7 & 0.7 & 6.9 & 12.5 & 5.7 & 10.3 & 4.7 & - \\
\hline \multirow[t]{3}{*}{ Accessories } & 3.1 & 3.4 & 3.4 & 1.7 & 3.7 & 2.2 & 3.9 & 2.3 & 2.8 & 2.1 \\
\hline & 100.0 & 100.0 & 100.0 & 100.0 & 100.0 & 100.0 & 100.0 & 100.0 & 100.0 & 100.0 \\
\hline & 11 & 12 & 13 & 14 & 15 & 16 & 17 & 18 & \multicolumn{2}{|l|}{ Average } \\
\hline Quartz & 19.9 & 18.2 & 23.2 & 19.8 & 10.7 & 28.5 & 25.8 & 23.4 & \multicolumn{2}{|l|}{16.8} \\
\hline Plagioclase & 52.2 & 44.0 & 50.6 & 54.2 & 50.5 & 49.7 & 50.0 & 55.0 & \multirow{2}{*}{\multicolumn{2}{|c|}{$\begin{array}{c}51.6 \\
(35)\end{array}$}} \\
\hline$(\mathrm{An})$ & $(32)$ & $(35-20)$ & $(40-35)$ & $(30)$ & $(35-30)$ & $(35-28)$ & $(45-35)$ & $(35-25)$ & & \\
\hline Biotite & 25.9 & 35.6 & 21.0 & 21.7 & 38.8 & 20.9 & 23.1 & 18.3 & \multicolumn{2}{|l|}{25.0} \\
\hline Hornblende & - & - & 3.2 & 3.8 & - & - & 0.3 & - & \multicolumn{2}{|l|}{4.4} \\
\hline Accessories & 2.0 & 2.2 & 2.0 & 0.5 & $\operatorname{tr}$ & 0.9 & 0.3 & 3.3 & \multicolumn{2}{|l|}{2.2} \\
\hline & 100.0 & 100.0 & 100.0 & 100.0 & 100.0 & 100.0 & 100.0 & 100.0 & \multicolumn{2}{|l|}{100.0} \\
\hline
\end{tabular}

Accessories:

1. sphene, apatite, orthite, epidote, zircon

2. sphene, epidote, zircon, apatite, orthite, opaques, microcline

3. opaques, apatite, sericite, orthite, zircon

4. apatite, zircon, orthite

5. opaques $2.0 \%$, orthite, sphene, rutile, zircon, apatite $1.7 \%$

6. opaques, apatite

7. opaques, sphene, epidote, sericite, apatite, orthite, zircon

8. sphene, opaques, apatite, orthite

9. apatite, orthite, zircon, opaques

10. chlorite, sphene, sericite, microcline, saussurite, opaques, apatite, orthite, zircon

11. chlorite, apatite, opaques, zircon, epidote, sphene, microcline

12. opaques, apatite, sericite, orthite, zircon

13. microcline, sphene, apatite, orthite, sericite, zircon

14. sphene, apatite, zircon

15. opaques, apatite, zircon

16. apatite, sphene, zircon, orthite, microcline

17. sphene, apatite, orthite, zircon, opaques

18. microcline, sericite, chlorite, apatite, orthite, zircon

contain appreciable plagioclase, ilmenite and sphene inclusions. The refractive index determinations indicate that the compositions of hornblende in two samples can be expressed (according to Freund, 1955, p. 163) as $\mathrm{Mg}_{60} \mathrm{Fe}_{40} \quad(\gamma=1.675)$ and $\mathrm{Mg}_{45} \mathrm{Fe}_{5 \check{5}} \quad(\gamma=$ 1.688). Quartz occurs as small grains. There are numerous accessories (Table 1) and the dykes occasionally contain almandine $(\mathrm{n}=$ 1.792) mottles 1.5 to $2 \mathrm{~cm}$ in diameter.

The crosscutting mode of occurrence of the dykes is clearly shown in the texture; see the photomicrograph (Fig. 7) of the contact between the quartzite and a dyke.

The modal mineral composition given in Table 1 shows that the abundances of plagioclase, biotite and hornblende vary randomly as a function of quartz and do not exhibit any functional relation to the quartz.

Plotted in Fig. 8 is the abundance of hornblende against that of quartz. The figure demonstrates that the hornblende/quartz ratio of the dykes is scattered, probably owing to contamination. 


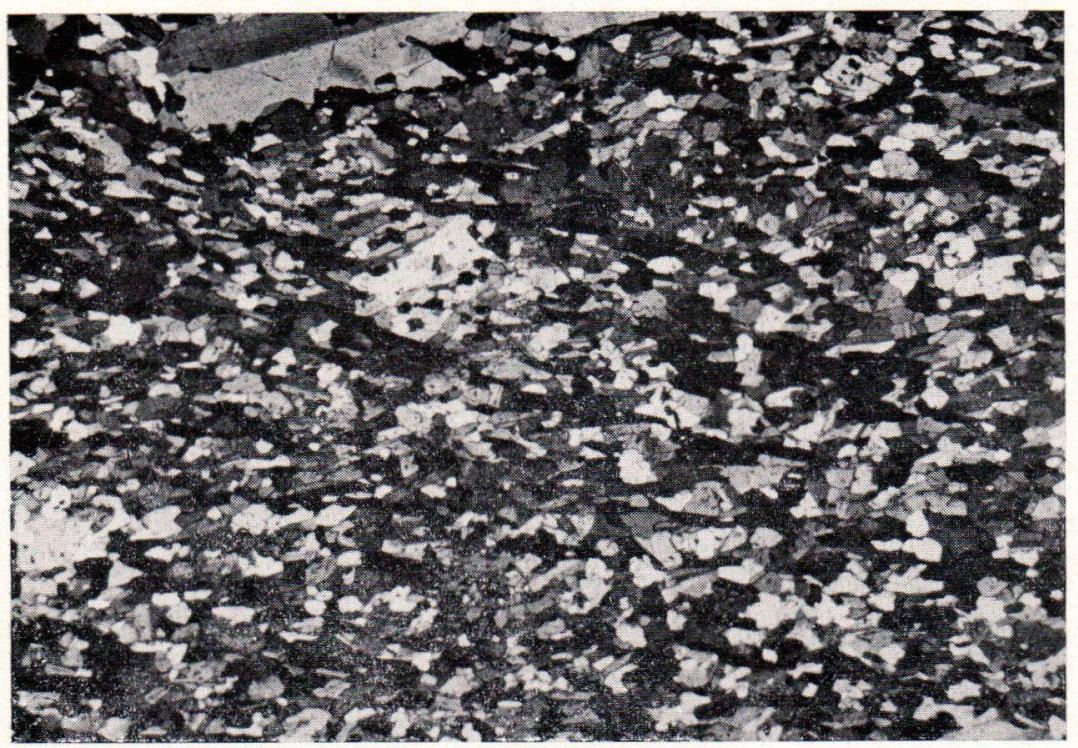

Fig. 6. A microtonalite with plagioclase phenocrysts. $10 \mathrm{x}$. Nic. + . Photo E. Halme.

\section{Chemical composition}

Except for samples 5 and 15, which were analysed by wet-chemical methods (Huhma, 1975), the samples collected from the microtonalite dykes were assayed by XRF at the
Outokumpu Oy Geological Laboratory of Exploration. The analytical data of the dykes are listed in Table 2 .

The chemical composition is illustrated by a $\mathrm{MgO}-\mathrm{SiO}_{2}$ diagram (Fig. 9). The three samples richest in $\mathrm{SiO}_{2}$ (Nos 16-18) consti-
Fig. 7. The contact between quartzite and dyke (quartzite on the left). $10 x$. Nic. +. Photo E. Halme.

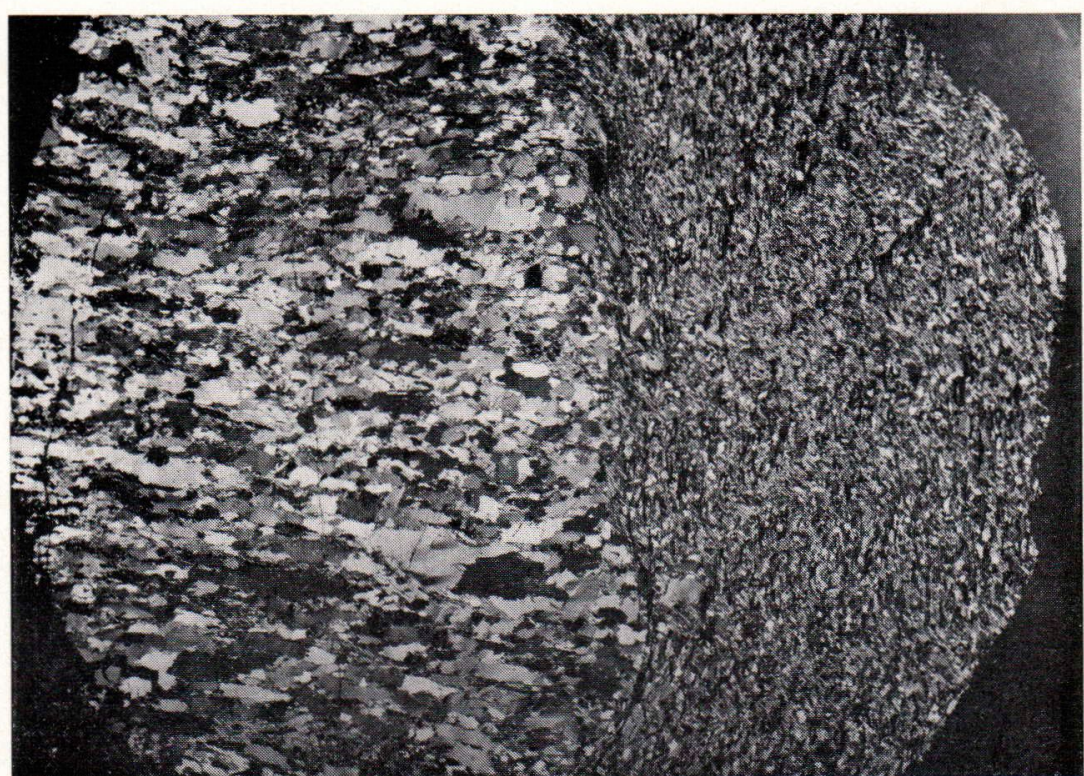


Table 2. Chemical compositions, Niggli values, and CIPW norms of some microtonalite dyke rocks.

\begin{tabular}{|c|c|c|c|c|c|c|c|c|c|c|c|c|c|c|c|c|c|c|}
\hline & 1 & 2 & 3 & 4 & 5 & 6 & 7 & 8 & 9 & 10 & 11 & 12 & 13 & 14 & 15 & 16 & 17 & 18 \\
\hline $\mathrm{SiO}_{2}$ & 53.45 & 54.59 & 54.61 & 56.39 & 56.8 & 56.82 & 56.83 & 56.88 & 56.97 & 56.98 & 57.42 & 57.54 & 57.65 & 57.87 & 59.27 & 64.34 & 67.36 & 68.55 \\
\hline $\mathrm{TiO}_{2}$ & 1.23 & 1.01 & 1.89 & 1.28 & 1.0 & 0.94 & 0.87 & 1.23 & 1.93 & 0.82 & 0.94 & 1.60 & 1.13 & 0.91 & 1.19 & 0.63 & 0.52 & 0.49 \\
\hline $\mathrm{Al}_{2} \mathrm{O}_{3}$ & 16.38 & 17.07 & 16.35 & 15.77 & 18.7 & 15.94 & 16.75 & 16.08 & 15.74 & 16.23 & 16.02 & 15.20 & 15.47 & 14.95 & 18.25 & 15.79 & 15.68 & 16.19 \\
\hline $\mathrm{FeO}$ & 8.31 & 7.10 & 9.27 & 9.29 & 7.551 & 6.37 & 5.90 & 8.20 & 8.45 & 5.95 & 6.54 & 9.59 & 7.19 & 8.37 & $6.07^{2}$ & 6.00 & 5.82 & 5.03 \\
\hline $\mathrm{MnO}$ & 0.07 & 0.03 & 0.06 & 0.05 & 0.10 & 0.02 & 0.02 & 0.07 & 0.05 & 0.03 & 0.03 & 0.09 & 0.04 & 0.07 & 0.08 & 0.02 & 0.02 & 0.01 \\
\hline MgO & 3.98 & 4.03 & 3.30 & 3.28 & 3.22 & 3.02 & 3.38 & 2.41 & 2.71 & 3.21 & 2.84 & 2.80 & 2.40 & 2.08 & 3.20 & 1.17 & 1.24 & 0.87 \\
\hline $\mathrm{CaO}$ & 6.71 & 5.68 & 5.48 & 3.97 & 6.25 & 5.24 & 6.09 & 6.35 & 6.10 & 4.78 & 3.65 & 3.56 & 4.55 & 3.98 & 4.37 & 3.75 & 4.47 & 3.51 \\
\hline $\mathrm{Na}_{2} \mathrm{O}$ & 2.48 & 3.32 & 1.29 & 3.19 & 3.70 & 3.45 & 3.49 & 4.33 & 2.42 & 2.08 & 3.14 & 3.07 & 3.06 & 3.81 & 2.83 & 3.87 & 2.73 & 4.18 \\
\hline $\mathrm{K}_{2} \mathrm{O}$ & 1.97 & 1.81 & 2.84 & 3.13 & 1.75 & 1.53 & 1.77 & 1.82 & 2.14 & 2.55 & 2.45 & 3.20 & 2.24 & 2.22 & 2.80 & 1.66 & 1.58 & 1.71 \\
\hline \multirow[t]{2}{*}{$\mathrm{P}_{2} \mathrm{O}_{5}$} & 0.62 & 0.38 & 0.85 & 0.53 & 0.24 & 0.45 & 0.37 & 0.62 & 0.78 & 0.36 & 0.33 & 0.69 & 0.51 & 0.44 & 0.31 & 0.41 & 0.31 & 0.31 \\
\hline & 95.20 & 95.02 & 95.94 & 96.88 & 99.313 & 93.78 & 95.47 & 97.99 & 97.30 & 92.99 & 93.36 & 97.34 & 94.24 & 94.70 & $98.42^{4}$ & 97.64 & 99.73 & 100.85 \\
\hline
\end{tabular}

Niggli values

\begin{tabular}{|c|c|c|c|c|c|c|c|c|c|c|c|c|c|c|c|c|c|c|}
\hline si & 157 & 168 & 187 & 180 & 170 & 195 & 184 & 177 & 186 & 203 & 207 & 191 & 206 & 204 & 193 & 258 & 276 & 286 \\
\hline al & 28.4 & 31.0 & 30.8 & 29.7 & 32.6 & 32.2 & 31.9 & 29.5 & 30.2 & 34.0 & 34.1 & 29.8 & 32.5 & 31.1 & 35.2 & 37.4 & 37.8 & 39.8 \\
\hline $\mathrm{fm}$ & 39.7 & 36.8 & 40.7 & 40.5 & 33.3 & 33.8 & 32.3 & 32.7 & 36.4 & 34.8 & 35.1 & 40.8 & 34.3 & 35.8 & 34.4 & 27.2 & 27.6 & 23.0 \\
\hline c & 21.1 & 18.7 & 18.8 & 13.6 & 20.0 & 19.2 & 21.1 & 21.1 & 21.3 & 18.2 & 14.1 & 12.7 & 17.4 & 15.0 & 15.3 & 16.1 & 19.6 & 15.7 \\
\hline alk & 10.8 & 13.5 & 9.8 & 16.2 & 14.1 & 14.8 & 14.6 & 16.7 & 12.1 & 13.0 & 16.6 & 16.7 & 15.7 & 18.0 & 15.1 & 19.3 & 15.0 & 21.5 \\
\hline $\mathrm{k}$ & 0.34 & 0.26 & 0.59 & 0.39 & 0.24 & 0.23 & 0.25 & 0.22 & 0.37 & 0.45 & 0.34 & 0.41 & 0.32 & 0.28 & 0.39 & 0.22 & 0.28 & 0.21 \\
\hline $\mathrm{mg}$ & 0.44 & 0.50 & 0.39 & 0.38 & 0.43 & 0.46 & 0.50 & 0.34 & 0.36 & 0.49 & 0.44 & 0.34 & 0.37 & 0.31 & 0.45 & 0.26 & 0.27 & 0.24 \\
\hline $\mathrm{ti}$ & 2.7 & 2.3 & 4.5 & 3.1 & 2.3 & 2.4 & 2.1 & 2.9 & 4.7 & 2.2 & 2.6 & 4.0 & 3.0 & 2.4 & 0.9 & 1.9 & 1.6 & 1.5 \\
\hline $\mathrm{p}$ & 0.8 & 0.4 & 1.1 & 0.7 & 0.2 & 0.7 & 0.5 & 0.8 & 1.1 & 0.5 & 0.5 & 1.0 & 0.8 & 0.7 & 0.4 & 0.7 & 0.5 & 0.5 \\
\hline
\end{tabular}

CIPW norms

\begin{tabular}{|c|c|c|c|c|c|c|c|c|c|c|c|c|c|c|c|c|c|c|}
\hline Q & 6.6 & 5.9 & 15.6 & 7.1 & 5.5 & 11.8 & 9.0 & 5.1 & 14.1 & 16.7 & 13.9 & 10.7 & 14.2 & 10.5 & 14.3 & 22.3 & 30.4 & 25.0 \\
\hline $\mathrm{C}$ & & 0.1 & 3.2 & 1.2 & & 0.2 & & & 0.2 & 2.2 & 2.3 & 1.9 & 1.0 & 0.1 & 3.3 & 1.8 & 2.1 & 1.8 \\
\hline Or & 11.6 & 10.7 & 16.8 & 18.5 & 10.3 & 9.0 & 10.5 & 10.8 & 12.6 & 15.1 & 14.5 & 18.9 & 13.2 & 13.1 & 16.5 & 9.8 & 9.3 & 10.1 \\
\hline $\mathrm{Ab}$ & 21.0 & 28.1 & 10.9 & 27.0 & 31.3 & 29.2 & 29.5 & 36.6 & 20.5 & 17.6 & 26.6 & 26.0 & 25.9 & 32.2 & 24.4 & 32.7 & 23.1 & 35.4 \\
\hline An & 27.7 & 26.0 & 21.6 & 16.2 & 29.2 & 23.0 & 24.8 & 19.1 & 25.2 & 21.4 & 16.0 & 13.1 & 19.2 & 16.9 & 19.7 & 15.9 & 20.1 & 15.4 \\
\hline Di & 1.3 & & & & 0.2 & & 2.5 & 7.1 & & & & & & & & & & \\
\hline $\mathrm{Hy}$ & 23.9 & 21.5 & 22.2 & 23.2 & 20.3 & 17.7 & 16.6 & 15.5 & 19.2 & 17.6 & 17.5 & 22.1 & 17.4 & 19.2 & 17.3 & 12.9 & 13.0 & 10.6 \\
\hline Il & 2.3 & 1.9 & 3.6 & 2.4 & 1.9 & 1.8 & 1.7 & 2.3 & 3.7 & 1.5 & 1.8 & 3.0 & 2.1 & 1.7 & 2.2 & 1.2 & 1.0 & 1.0 \\
\hline $\mathrm{Ap}$ & 1.5 & 0.8 & 2.0 & 1.3 & 0.6 & 1.1 & 0.9 & 1.5 & 1.8 & 0.9 & 0.8 & 1.6 & 1.2 & 1.0 & 0.7 & 1.0 & 0.7 & 0.7 \\
\hline & 95.9 & 95.0 & 95.9 & 96.9 & 99.3 & 93.8 & 95.5 & 98.0 & 97.3 & 93.0 & 93.4 & 97.3 & 94.2 & 94.7 & 98.4 & 97.6 & 99.7 & 100.9 \\
\hline
\end{tabular}



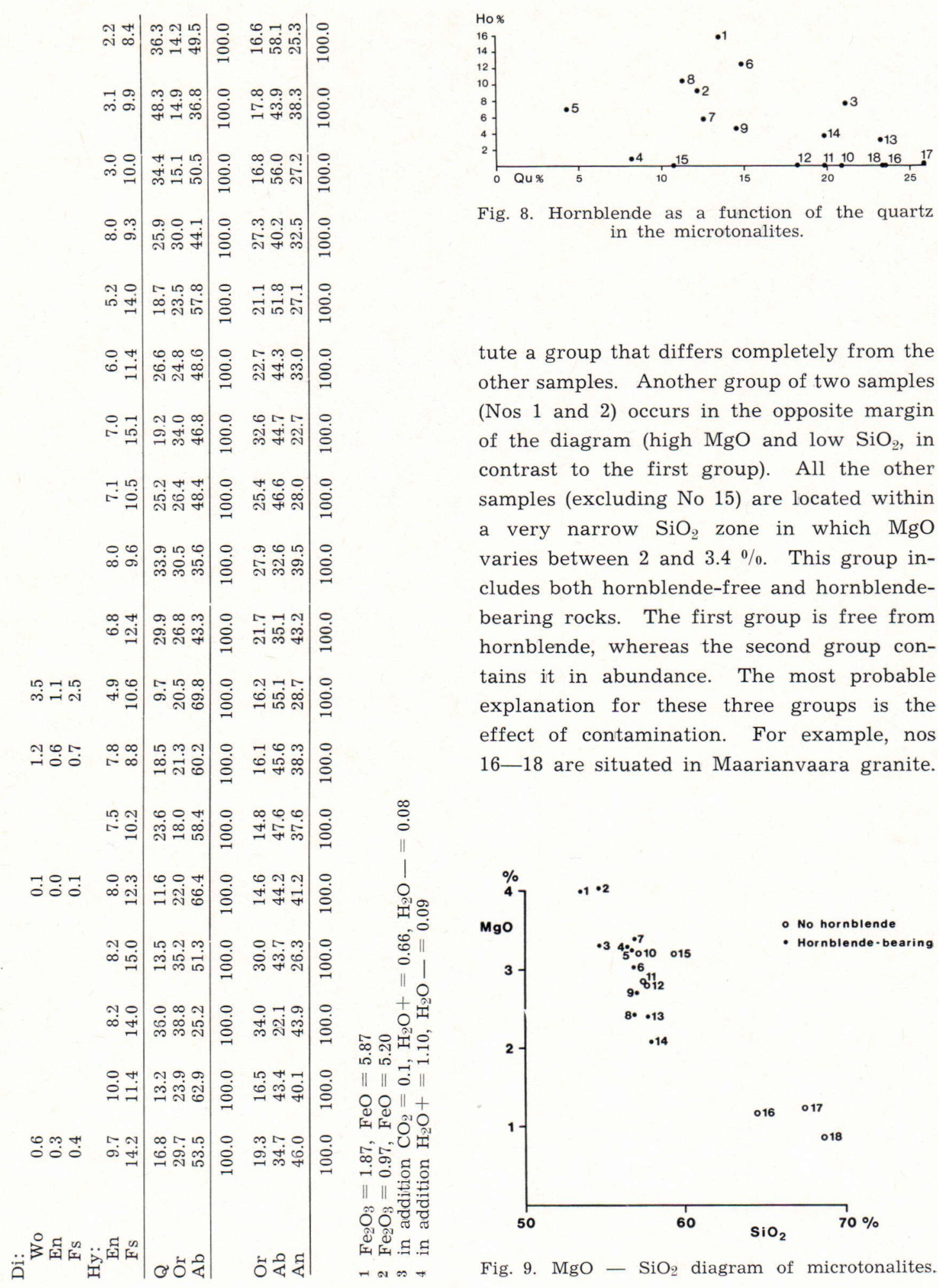

Fig. 8. Hornblende as a function of the quartz in the microtonalites.

tute a group that differs completely from the other samples. Another group of two samples (Nos 1 and 2) occurs in the opposite margin of the diagram (high $\mathrm{MgO}$ and low $\mathrm{SiO}_{2}$, in contrast to the first group). All the other samples (excluding No 15) are located within a very narrow $\mathrm{SiO}_{2}$ zone in which $\mathrm{MgO}$ varies between 2 and $3.4 \%$. This group includes both hornblende-free and hornblendebearing rocks. The first group is free from hornblende, whereas the second group contains it in abundance. The most probable explanation for these three groups is the effect of contamination. For example, nos 16-18 are situated in Maarianvaara granite.

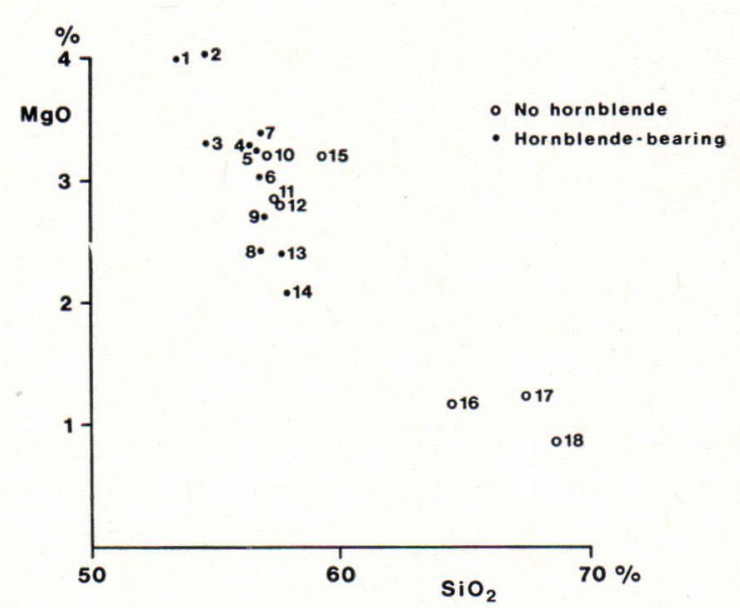

Fig. 9. $\mathrm{MgO}-\mathrm{SiO}_{2}$ diagram of microtonalites. 


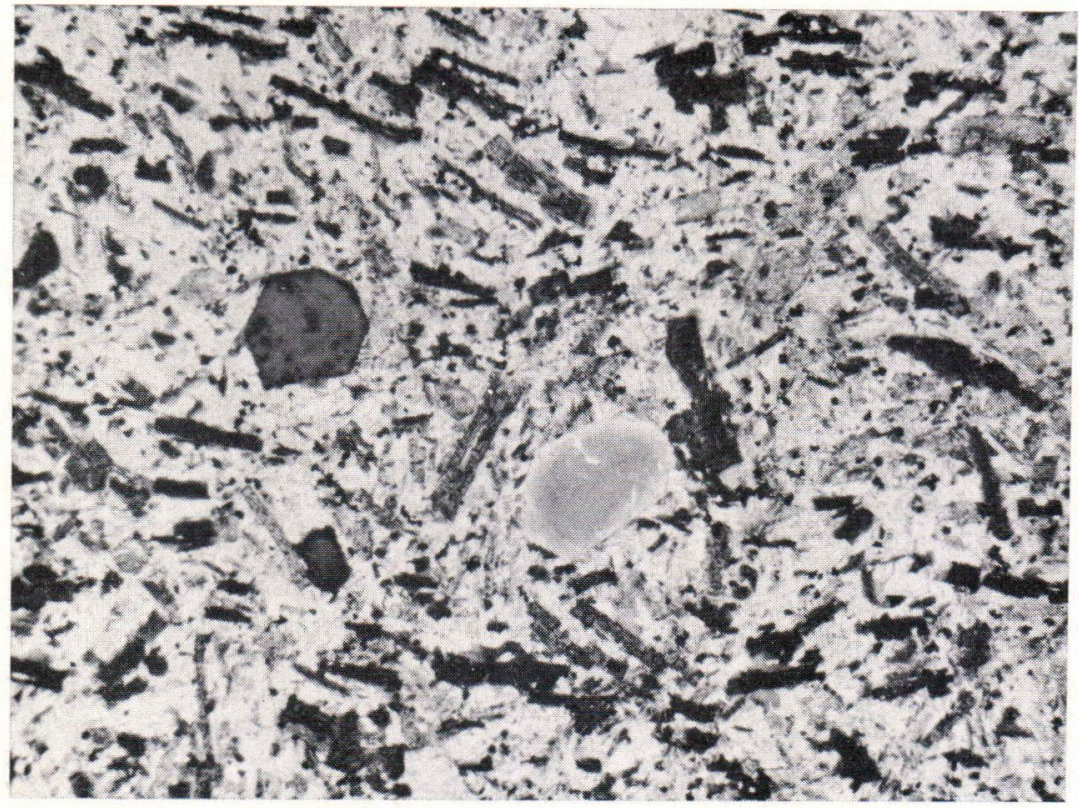

Fig. 10. Photomicrograph of lamprophyre. Biotite (dark) and apatite (light) phenocrysts clearly visible. 20x. Nic.-. Photo E. Hänninen.

\section{Lamprophyre dykes}

\section{Mode of occurrence}

In addition to those described by Hackman (1914), the Exploration Dept. of Outokumpu Oy has discovered more lamprophyre dykes, bringing the current number of known dykes or dyke swarms up to six (Fig. 1). The width of the dykes varies from a few centimetres to 70 centimetres, but usually from 25 to 50 centimetres. In some localities the dykes have been encountered in only one outcrop, whereas in others they can be traced for over 100 metres from one outcrop to the next. The dykes usually occur alone, but in some places two or three parallel dykes lie close together.

The contacts of the dykes are very sharp and rectilinear. The predominating trend is N73W; only rarely do they depart from this direction and then very slightly. The dip is subvertical to vertical. The dykes cut both the basement gneiss and the pegmatine veins in it. Locally they include small fragments of country rock.

\section{Petrography}

The rock is dark grey or almost black and fine-grained with numerous small mica flakes. Some of the micas occur as large bundles one square centimetre or more in size. Phenocrysts of other minerals are also present, but they are not as characteristic and conspicuous as is the mica (Fig. 10).

The groundmass consists of very finegrained biotite, plagioclase (c. $\mathrm{An}_{20}$ ), potassium feldspar, quartz, apatite, carbonate, epidote, ilmenite, sphene, rutile, spinel, barite and zircon. The mineral composition was determined by $\mathrm{X}$-ray techniques, the rock being too fine-grained for the minerals to be identified with certainty by optic methods. Biotite, augite, apatite, orthoclase, calcite and quartz occur as pehnocyrsts, whereas calcite and quartz often exist as the filling of amygdules.

\section{Chemical composition}

Two wet-chemical analyses of the lamprophyre dykes are given: the first one is by 
Table 3. Chemical composition of the lamprophyre dykes.

\begin{tabular}{|c|c|c|c|}
\hline & 1 & 2 & \\
\hline $\mathrm{SiO}_{2}$ & 43.40 & 45.51 & \\
\hline $\mathrm{TiO}_{2}$ & 1.98 & 1.61 & \\
\hline $\mathrm{ZrO}_{2}$ & n.d. & 0.13 & \\
\hline $\mathrm{Al}_{2} \mathrm{O}_{3}$ & 12.71 & 13.43 & \\
\hline $\mathrm{Cr}_{2} \mathrm{O}_{3}$ & n.d. & 0.01 & \\
\hline $\mathrm{Fe}_{2} \mathrm{O}_{3}$ & 1.94 & 3.27 & \\
\hline $\mathrm{FeO}$ & 5.80 & 5.25 & \\
\hline $\mathrm{MnO}$ & 0.34 & 0.12 & \\
\hline $\mathrm{MgO}$ & 8.64 & 5.78 & \\
\hline $\mathrm{CaO}$ & 9.67 & 7.72 & \\
\hline $\mathrm{BaO}$ & n.d. & 1.19 & \\
\hline $\mathrm{SrO}$ & n.d. & 0.60 & \\
\hline $\mathrm{Na}_{2} \mathrm{O}$ & 3.06 & 3.84 & \\
\hline $\mathrm{K}_{2} \mathrm{O}$ & 4.66 & 3.94 & \\
\hline $\mathrm{P}_{2} \mathrm{O}_{5}$ & 3.44 & 2.91 & \\
\hline $\mathrm{S}$ & 0.27 & 0.22 & \\
\hline $\mathrm{Cl}$ & 0.10 & n.d. & \\
\hline $\mathrm{CO}_{2}$ & 2.56 & 1.34 & \\
\hline $\mathrm{H}_{2} \mathrm{O}+$ & 0.78 & 1.24 & \\
\hline \multirow[t]{7}{*}{$\mathrm{H}_{2} \mathrm{O}-$} & 0.17 & 0.33 & \\
\hline & 99.52 & 98.44 & \\
\hline & & 108 & $\mathrm{ppm}$ \\
\hline & & 218 & $»$ \\
\hline & & 75 & $»$ \\
\hline & - & 38 & $»$ \\
\hline & & 150 & $»$ \\
\hline
\end{tabular}

1. The analysis by Hackman (1914)

2. The analysis of the sample A159 n.d. $=$ not determined

Hackman (1914) (No 1 in Table 3) and the other that of sample A159 (No 2 in Table 3), analysed at the Outokumpu Oy Geological Laboratory of Exploration.

The chemical composition indicates that these rocks contain conspicuous amounts of $\mathrm{K}$ and $\mathrm{P}$. Their $\mathrm{Ba}, \mathrm{Sr}$, and $\mathrm{Zr}$ contents are also marked.

Comparison of the chemical compositions, normative minerals and Niggli values of the camptonites (1-5) and lamprophyres in Kaavi (6-7) (Table 4) indicates the dissimilarities between these groups. See also Fig. 11.

\section{Dating}

Two samples were dated: one from a microtonalite dyke (A940) at Mäntyjärvi, Kaavi, on map sheet 4311 05D (6996.60/435.09) and one from a lamprophyre dyke (A159), at Niinivaara, Kaavi, on map sheet 4311 07B (6988.78/ 442.94) (see Fig. 1 and Table 5).

The microtonalite dyke occurs in Karelian quartzite (Fig. 5) and the lamprophyre dyke in Prekarelian gneiss. The datings were based on zircon and sphene (Table 5).

The age of the lamprophyre dyke was determined from three zircon fractions (Fig. 12). The zircon in fraction $A$ is clear and seems to have existed in large crystals that were broken during crushing. This zircon fraction gives an age of $1830 \mathrm{Ma}$, which is also the age of the dyke.

The zircons in fraction $\mathrm{C}$ are rounded. They show an age of $2460 \mathrm{Ma}$ according to the continuous diffusion model of Wasserburg (1963) and are obviously from an external source. Fraction B is an admixture. The results of the sphene datings are summarized in Table 5 and in Fig. 12.

The zircon grains separated from the microtonalite dyke (A940, Table 5) were all rounded and residual and gave an age of $2640 \mathrm{Ma}$ according to the continuous diffusion model

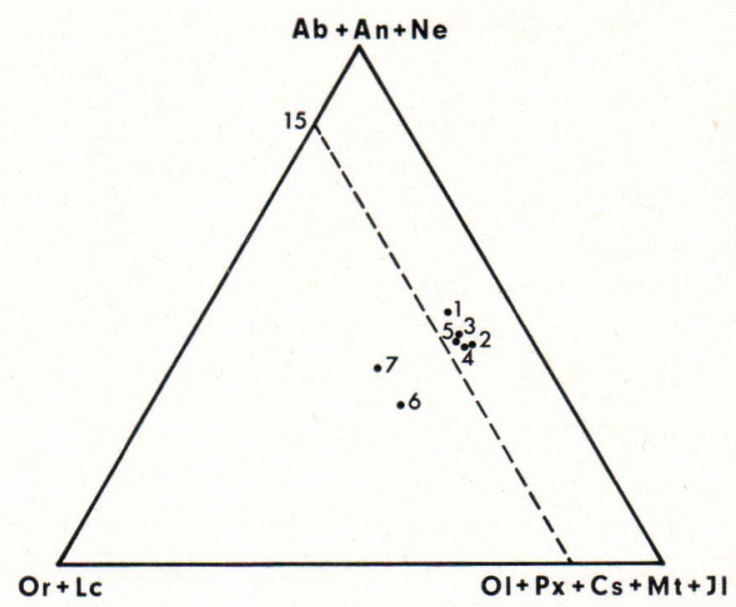

Fig. 11. Composition of the lamprophyres in the Table 4. Diagram after Fig. 2 by Rock (1977, p. 136). Dashed line indicates the basalt screen of Manson (1967) 
Table 4. Chemical compositions, CIPW norms and Niggli values of lamprophyres.

\begin{tabular}{|c|c|c|c|c|c|c|c|}
\hline & 1 & 2 & 3 & 4 & 5 & 6 & 7 \\
\hline $\mathrm{SiO}_{2}$ & 40.70 & 44.4 & 44.67 & 43.01 & 42.96 & 43.40 & 45.51 \\
\hline $\mathrm{TiO}_{2}$ & 3.86 & 3.3 & 3.26 & 2.72 & 2.75 & 1.98 & 1.61 \\
\hline $\mathrm{Al}_{2} \mathrm{O}_{3}$ & 16.02 & 14.3 & 14.35 & 14.64 & 14.82 & 12.71 & 13.43 \\
\hline $\mathrm{Fe}_{2} \mathrm{O}_{3}$ & 5.43 & 3.9 & 4.50 & 4.83 & 4.64 & 1.94 & 3.27 \\
\hline $\mathrm{FeO}$ & 7.84 & 7.4 & 7.19 & 7.26 & 7.44 & 5.80 & 5.25 \\
\hline $\mathrm{MnO}$ & 0.16 & n.m. & n.m. & n.m. & n.m. & 0.34 & 0.12 \\
\hline $\mathrm{MgO}$ & 5.43 & 7.1 & 7.02 & 6.78 & 6.68 & 8.64 & 5.78 \\
\hline $\mathrm{CaO}$ & 9.36 & 10.6 & 9.45 & 10.25 & 10.18 & 9.67 & 7.72 \\
\hline $\mathrm{Na}_{2} \mathrm{O}$ & 3.23 & 3.2 & 2.99 & 3.27 & 3.41 & 3.06 & 3.84 \\
\hline $\mathrm{K}_{2} \mathrm{O}$ & 1.76 & 1.7 & 1.91 & 1.90 & 2.02 & 4.66 & 3.94 \\
\hline \multirow[t]{2}{*}{$\mathrm{P}_{2} \mathrm{O}_{5}$} & 0.62 & n.m. & n.m. & n.m. & 0.71 & 3.44 & 2.91 \\
\hline & 94.41 & 95.9 & 95.34 & 94.66 & 95.61 & 95.64 & 93.83 \\
\hline \multicolumn{8}{|c|}{ CIPW norms } \\
\hline Or & 10.40 & 10.05 & 11.29 & 11.23 & 11.94 & 13.81 & 23.28 \\
\hline $\mathrm{Ab}$ & 14.09 & 13.36 & 17.55 & 10.14 & 12.02 & 12.35 & 23.06 \\
\hline An & 24.02 & 19.63 & 20.10 & 19.66 & 19.17 & 7.18 & 7.77 \\
\hline Lc & - & - & - & - & - & 10.76 & - \\
\hline $\mathrm{Ne}$ & 7.17 & 7.43 & 4.20 & 9.50 & 9.12 & 7.34 & 5.11 \\
\hline $\mathrm{D}_{\mathrm{i}}^{\mathrm{i}}$ & 14.67 & 26.30 & 21.31 & 24.92 & 21.37 & 14.64 & 9.21 \\
\hline $\mathrm{Hy}$ & 7.42 & - & - & - & - & - & - \\
\hline $\mathrm{Ol}$ & - & 7.20 & 8.19 & 7.06 & 8.40 & 15.02 & 10.40 \\
\hline Mt & 7.87 & 5.66 & 6.53 & 7.00 & 6.73 & 2.81 & 4.74 \\
\hline Il & 7.33 & 6.27 & 6.20 & 5.20 & 5.22 & 3.76 & 3.06 \\
\hline Ap & 1.47 & n.m. & n.m. & n.m. & 1.68 & 8.15 & 6.89 \\
\hline \multicolumn{8}{|c|}{ Niggli values } \\
\hline si & 96 & 102 & 105 & 98 & 98 & 100 & 120 \\
\hline al & 22.2 & 19.3 & 19.9 & 19.7 & 19.9 & 17.3 & 20.8 \\
\hline $\mathrm{fm}$ & 44.3 & 45.1 & 46.7 & 45.2 & 44.8 & 45.0 & 41.0 \\
\hline c & 23.5 & 26.0 & 23.8 & 25.1 & 24.8 & 23.9 & 21.8 \\
\hline alk & 10.0 & 9.6 & 9.7 & 10.0 & 10.5 & 13.9 & 16.4 \\
\hline $\mathrm{k}$ & 0.26 & 0.29 & 0.30 & 0.28 & 0.28 & 0.50 & 0.40 \\
\hline $\mathrm{mg}$ & 0.43 & 0.54 & 0.53 & 0.51 & 0.51 & 0.66 & 0.55 \\
\hline $\mathrm{ti}$ & 6.82 & 5.68 & 5.78 & 4.67 & 4.71 & 3.44 & 3.19 \\
\hline $\mathrm{p}$ & 0.62 & n.m. & n.m. & n.m. & 0.69 & 3.37 & 3.24 \\
\hline
\end{tabular}

1. Average of 15 camptonites (Johannsen, op.cit., Vol. IV, p. 65)

2. Average of 14 camptonites (Nockolds, 1954)

3. Average of 78 camptonites (Metais and Chayes, 1963)

4. Average of 107 camptonites (Rock, 1977)

5. Estimated mean composition of 95 camptonites (Rock, 1977)

6. Lamprophyre by Hackman (1914)

7. Sample A159

n.m. = not mentioned

of Wasserburg (1963); thus an external source is suggested.

The microtonalite dyke contains abundant sphene with an age of $1850 \mathrm{Ma}$. It is, however, unknown whether this can be taken as the age of the dyke or whether the sphene is metamorphic in origin.

\section{Discussion}

\section{Microtonalites}

The microtonalites are fine-grained dyke rocks of tonalitic (or quartz dioritic) composition. 


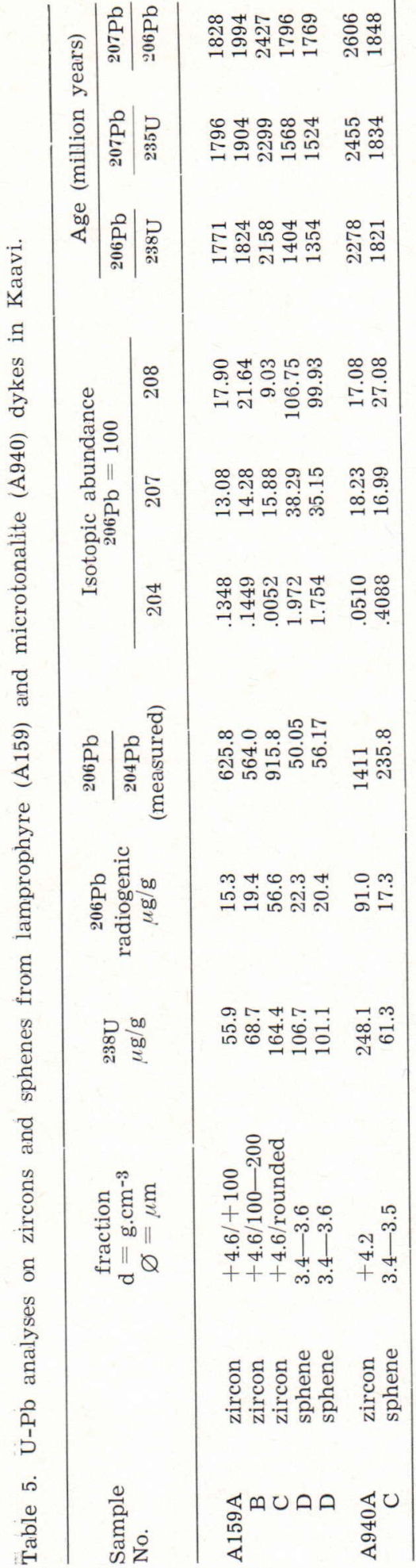

The usage of the terms tonalite and quartz diorite is somewhat ambiguous in the literature and often refers to the same rock.

Joplin (1964) calls rocks with less than $10 \%$ quartz, quartz diorite and those with more than $10 \%$ quartz, tonalite.

In the classification by Johannsen (1941, Vol. II, p. 378), all the rocks described in the present paper fall into the class of tonalites $228 \mathrm{P}$. His quartz boundary is at $5 \%$.

Referring to tonalites, Shand (1949) states: "This division includes all oversaturated rocks in which the anorthite molecule exceeds the orthoclase molecule, regardless of the nature of the dark minerals".

According to the system by Shand, the rocks under consideration belong to tonalites, more precisely to indices $\mathrm{XO} \gamma$ and $\mathrm{XO} \delta$. Samples 4 and 14 (index $\mathrm{XO} \beta$ ), however, Shand would have considered as granodiorites.

According to the more recent classification by IUGS (1973) the rock samples in Table 1 are tonalites but some of them are close to quartz diorite; No 5 is the only quartz diorite.

The comparison between the mean of the 18 microtonalites in this paper and that of the 19 tonalites of Johannsen (Johannsen, op. cit. Vol. II, p. 386) shows that the similarity is not very conspicuous (Table 6).

On the other hand, the Niggli values of the mean of the microtonalites (No 1) are quite close to that of Niggli's tonalitic magma type (No 2) (Niggli, op. cit.):

\begin{tabular}{lcc}
\hline Niggli values & 1 & 2 \\
\hline $\mathrm{si}$ & 201 & 200 \\
$\mathrm{al}$ & 32.7 & 33 \\
$\mathrm{fm}$ & 34.4 & 33 \\
$\mathrm{c}$ & 17.7 & 22 \\
$\mathrm{alk}$ & 15.2 & 12 \\
$\mathrm{k}$ & 0.32 & 0.40 \\
$\mathrm{mg}$ & 0.39 & 0.50 \\
$\mathrm{ti}$ & 2.6 & n.d. \\
$\mathrm{p}$ & 0.7 & n.d. \\
\hline
\end{tabular}




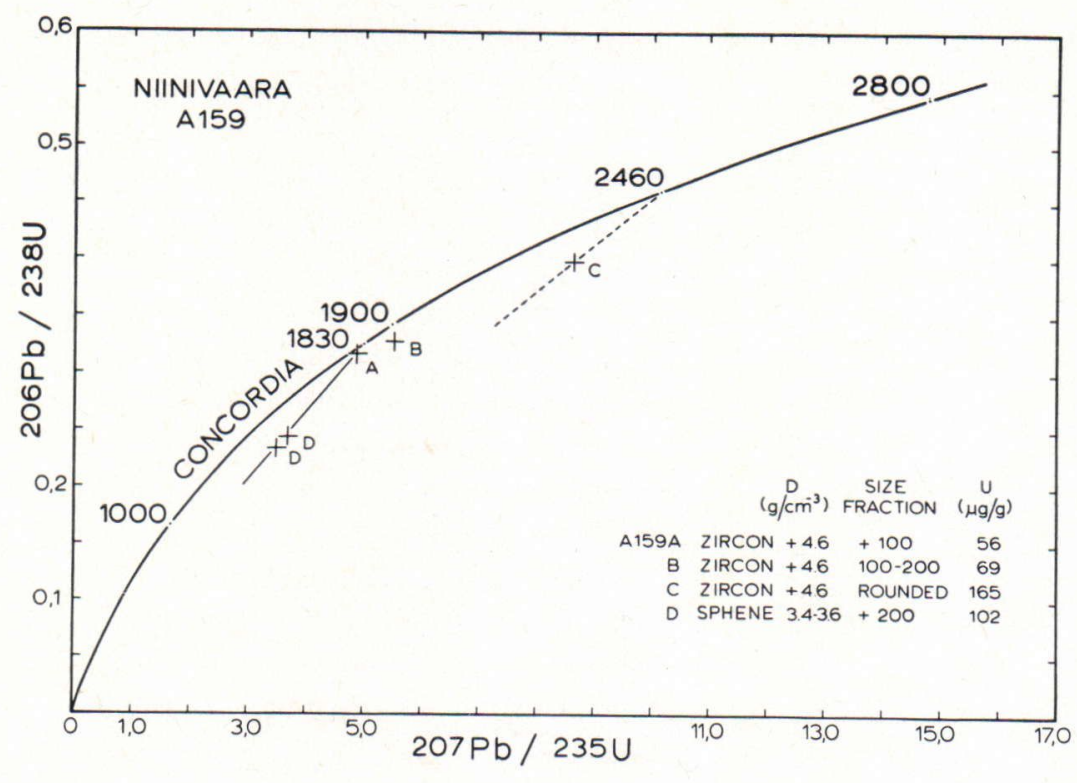

Fig. 12. Concordia diagram for $\mathrm{U}-\mathrm{Pb}$ ratios of zircons and sphene. Lamprophyre A159, Niinivaara, Kaavi.
The age of the microtonalite dykes has not been established for sure because the dyke only contains residual zircons (2460 $\mathrm{Ma})$. The sphene age, $1850 \mathrm{Ma}$, can be interpreted as the age of metamorphism. Geological evidence, however, suggests that it is also the age of the dyke.

The microtonalite dykes crosscut the Maarianvaara granite the age of which is $1860 \mathrm{Ma}$. The other limit of the age is set by the lamprophyre dyke that is $1830 \mathrm{Ma}$ old.

According to Rock (1977, p. 125), lamprophyres are always the latest manifestation of igneous activity in a given region, accompanying aplites, pegmatites or carbonatites. Thus the age of the microtonalite dykes probably falls between $1860 \mathrm{Ma}$ and $1830 \mathrm{Ma}$. There is no reason to doubt that the real age of the microtonalite dykes is about $1850 \mathrm{Ma}$.

\section{Lamprophyres}

Hackman (1914) called lamprophyre dykes camptonites and ouachitites.

According to the chemical composition, the dyke rock belongs to Niggli's shonkinitic magma type (Niggli, 1923, pp. 193, 395), as do most camptonites (Niggli, op. cit., p. 353). Hence the names used by Hackman, although comprehensible, are rejected in this paper.

The name camptonite (Johannsen, 1941, Vol. IV, p. 64) was given to dark grey to black dyke rocks of basaltic habit that occur as satellites of foyaitic and theralitic plutonites. They have not been found in the area now discussed.

According to Johannsen (op. cit.), camptonites contain phenocrysts of biotite, barkevikite and titanaugite, and often olivine in a fine-grained to dense groundmass. The groundmass consists of plagioclase laths and microlites of amphibole and augite.

According to Niggli, camptonites may also contain nepheline, leucite and other feldspathoides (Niggli, op. cit., pp. 214-215).

In the opinion of Streckeisen (1978) the mineral composition of camptonites includes amphibole (barkevikite, kaersutite), titanaugite, olivine, and/or biotite in a groundmass of labradorite, amphibole, pyroxene with subordinate alkaline feldspar and foids; \pm apatite, iron ore, calcite, zeolite etc. 
Rock (1977) gives the following data on of the camptonites:

\begin{tabular}{lcc}
\hline & $\begin{array}{c}\text { Olivine } \\
\text { free }\end{array}$ & $\begin{array}{c}\text { Olivine } \\
\text { bearing }\end{array}$ \\
\hline Amphibole only & 14 & 14 \\
$\# \quad+$ clinopyroxene & 40 & 56 \\
$\#$ \# + biotite & 13 & 18 \\
D + biotite & 10 & 6 \\
Clinopyroxene + biotite & 1 & 2 \\
Biotite only & - & - \\
\hline Totals & 78 & 92 \\
\hline
\end{tabular}

Ouachitites, the other name proposed by Hackman, are regarded as olivine-free biotite-monchiquites, which occur as dark dyke rocks in nepheline-syenite. The monchiquite in Ouachita River in Arkansas has the following mode: analcime 15 , dark mica 44 , pyroxene 26, magnetite and pyrite 6 , calcite 9 (Johannsen, op. cit., Vol. IV, pp. 391, 382, 384), (cf. Niggli, op. cit., p. 215).

The name ouachitite (and monchiquite) is thus obviously inappropriate to the lamprophyre discussed here.

The mineral composition of kersantites given by Streckeisen (op. cit.) is as follows: plagioclace (oligoclase-andesine), biotite, augite; \pm alkaline feldspar, hornblende, olivine, quartz, apatite, iron ore, calcite, etc.

According to Beuge and Kramer (1977, p. $80)$, the kersantites are alkali-, especially $\mathrm{K}$-dominant and they are also relatively rich in $\mathrm{P}, \mathrm{Ba}$, and $\mathrm{Zr}$.

Thus, the lamprophyre described in the present paper resembles kersantites to some degree, although kersantites are more acidic containing c. 50 per cent $\mathrm{SiO}_{2}$ (Metais \& Chayes, 1963).

Without renaming the rock under discussion, it can be described as 'biotite-lamprophyre of the shonkinitic magma type' (cf. Niggli, op. cit.), or 'mesocratic biotite-lamprophyre' (cf. Johannsen, op. cit.). Or why not
Table 6. Averages of the chemical compositions, Niggli values and CIPW norms of the microtonalites and tonalites.

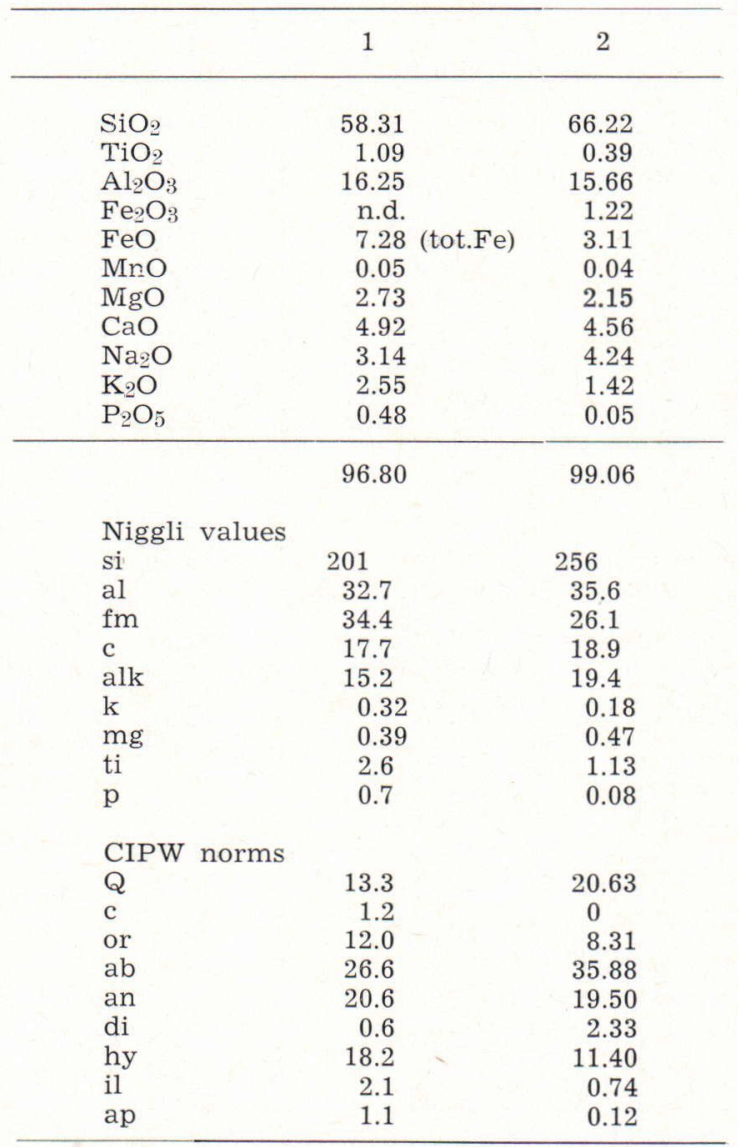

1. Average of the 18 microtonalites (Table 2)

2. Average of 19 tonalites (Johannsen, op.cit. Vol. II, p. 386)

call it 'niinilite' after the lake Niinilampi as already proposed by Hackman.

Rather than to discuss the name of the lamprophyre in Kaavi, the main purpose of the present work was to report the age, 1830 $\mathrm{Ma}$, of the youngest rock found in North Karelia.

Acknowledgements - The author is indebted to Outokumpu Oy for permission to publish this paper. The samples were chemically analysed at 
the Outokumpu Oy Geological Laboratory of Exploration. The age determinations were made at the Geological Survey of Finland by Mr Hannu Huhma. Dr. P. Rouhunkoski and Dr. T. A. Häkli read the manuscript and Mrs Gillian Häkli translated it into English. To all these persons I express my cordial thanks. And last but not least I thank my wife for her help.

\section{References}

Beuge, P. and Kramer, W. (1977) Lamprophyre Ostthüringens und ihre anomale Quecksilbergehalte im Ergebnis endogener und exogener Anreichungsprozesse. Schr. geol. Wiss., Berlin $8,79-99$.

Freund, H. (1955) Handbuch der Mikroskopie in der Technik. Bd. IV. Teil 1: Mikroskopie der Gesteine. Umschau Verlag, Frankfurt am Main.

Hackman, V. (1914) Über Camptonitgänge im mittleren Finnland. Bull. Comm. Géol. Finlande 42, $1-18$.

Huhma, A. (1970) Short description of the geology of the Outokumpu district. In Huhma, A. and Huhma, M., Contribution to the geology and geochemistry of the Outokumpu region. Bull. Geol. Soc. Finland 42, 57-88.

- (1971) Maps of the Pre-Quarternary rocks, 4222 Outokumpu, 4224 Kontiolahti and 4311 Sivakkavaara. Geological Map of Finland, $1: 100000$. Geological Survey of Finland.

- (1975) Precambrian rocks of the Outokumpu, Polvijärvi and Sivakkavaara map-sheet areas. English summary: 110-151. Suomen geologinen kartta, Kallioperäkartan selitykset 4222 Outokumpu, 4224 Polvijärvi, 4311 Sivakkavaara. Geological Survey of Finland.

- (1976) New aspects to the geology of the Outokumpu region. Bull. Geol. Soc. Finland 48, 5-24.

IUGS (1973) Plutonic rocks: Classification and nomenclature. Geotimes, October 1973, 26-30.

Johannsen, A. (1941) A descriptive petrography of the igneous rocks. Univ. of Chicago Press, Chicago, Illinois.
Joplin, G. (1964) A petrography of Australian igneous rocks. Angus and Robertson, p. 187.

Manson, V. (1967) Geochemistry of basaltic rocks: major elements. In: H. H. Hess and A. Poldervaart (Eds.), Basalts. Wiley, New York, N.Y., $215-270$.

Métais, D. and Chayes, F. (1963) Varieties of lamprophyre. Ann. Rep. Geophys. Lab., Wash. 02, 156-157.

Niggli, P. (1923) Gesteins- und Mineralprovinzen, Band I. Verlag von Gebrüder Borntraeger, Berlin.

Nockolds, S. R. (1954) Average compositions of some igneous rocks. Bull. Geol. Coc. Am., 65, $1007-1032$.

Rock, N. M. S. (1977) The nature and origin of lamprophyres: Some definitions, distinctions, and derivations. Earth Sci. Rev. 13 (1977), 123169 .

Shand, J. S. (1949) Eruptive rocks. Murby \& Co., London, 382-385.

Simonen, A. (1980) Precambrian in Finland. Geol. Surv. Finland Bull. 304, 58 pp.

Streckeisen, A. (1967) Classification and nomenclature of igneous rocks. N. Jb. Miner. Abh., 107, 2, p. 175.

- (1978) Classification and nomenclature of volcanic rocks, lamprophyres, carbonatites and melilitic rocks. N. Jb. Miner. Abh., 134, 1, 1-14.

Wasserburg, G. J. (1963) Diffusion processes in lead-uranium systems. J. Geophys. Res. 68, $4823-4846$.

Manuscript received, November 16, 1980. 